\title{
LITERACY, EDUCATION AND HEALTH DEVELOPMENT
}

\author{
Annotated Bibliography
}

ANNE DIEVLER

School of Public Health, University of Michigan, Ann Arbor, MI 48109, U.S.A.

The focus of this bibliography is education's effect on health status in developing countries. Some of the most relevant articles have been cited and annotated. The annotations are not summaries of the articles, but rather provide specific reference to the empirical evidence or, in some cases, lack of evidence for linking education with health status.

The bibliography has been divided into four sections: Studies citing evidence of an empirical association between education and mortality, studies focusing on education's effect on malnutrition and morbidity in children, studies in the United States which support the relationship between education and health status, and studies which focus on the mechanisms of interaction between education and health status. A more inclusive bibliographic list follows the annotations.

\section{Studies Citing Evidence of an Empirical Association Between Education and Mortality}

Behm, Hugo, "Socioeconomic Determinants of Mortality in Latin America," paper presented at WHO Meeting on Socioeconomic Determinants and Consequences of Mortality, June 1979.

An examination of the socioeconomic determinants of mortality in Latin America. Analyzed the risk of death between birth and two years of age in twelve Latin American countries in terms of education of mother. Found children of illiterate mothers have a risk of death 3.5-5.0 times greater than those of women who have reached ten or more years of education. Cites a modification of present social and economic structures as a necessary step to reduce high mortality found in Latin America.

Caldwell, John C., "Education as a Factor in Mortality Decline - An Examination of Nigerian Data," Population Studies, vol. 33, no. 3, November 1979.

Using data from Changing African Family Project Nigerian Segment Survey, this study shows marked child mortality differentials by education of mother. Education increases skills and knowledge as well as the ability to deal with new ideas and provides a vehicle for the import of a different culture. Hypotheses: 1) education changes the fatalist perspective of the family;2) with education a mother is better able to manipulate the modern world; 3) education changes the balance of familial relationships. This paper links both mortality and fertility to the same fundamental social changes. 
Cochrane, Susan H., "Educational Differentials in Mortality of Children," mimeographed paper, April 1980.

Examination of differentials in infant and child mortality by parental education within countries in LDC's. Found almost universal inverse relationship between maternal education and infant and child mortality. In bivariate analysis, found on the average, one additional year of schooling is associated with a reduction of mortality of about $9 / 1,000$; effect of years of schooling seems similar in urban and rural areas; countries differ substantially in the mortality differentials across educational groups; differentials among lowest educational groups seems smaller the higher the country's overall literacy rate and the greater the government health expenditures per capita; evidence that education's impact increases from the neonatal to the post-neonatal period and that education has its greatest influence on the mortality of children between one and four, multivariate analysis showed that evidence is mixed on whether maternal education's influence is greater or less than economic level of household. Results might indicate that direct policies such as increasing government expenditures on health and expenditures to reduce illiteracy might be more useful in reducing mortality differences than policies to increase income or reduce income inequality per se.

Cochrane, Susan H., "The Socioeconomic Determinants of Mortality: The Cross-National Evidence," discussion draft for WDR, January 2, 1980.

Review of major conclusions of literature on the determinants of mortality on the national level using aggregate data. Cross-national analysis: variate analy sis showed income is positively related to life expectancy above which increase in income will have no effect; bivariate analysis showed literacy or other measures of education are more closely related to mortality and life expectancy than is per capita income, particularly when samples are restricted to developing countries; additionally caloric intake and calories from animal sources are more important indicators of health for infants and young children than is income, and more important in samples containing only developing countries. Multivariate analysis showed literacy is the most important variable in the multivariate analysis of life expectancy which includes measures of per capita income; when income distribution is included, literacy continues to be most important variable; income distribution is second, while calories per capita ceases to be important and number of doctors becomes significant; infant mortality is not as well explained in general by socioeconomic variables as life expectancy; examination of changes over time; found socioeconomic variables differed in their relation to life expectancy and infant mortality over time; need to look at disaggregated data, to determine to what extent mortality differs depending on levels of income, and education in the family, holding constant aggregate levels of education and income in the community.

Grosse, Robert N. and Perry, Barbara H., "Correlates of Life Expectancy in Less Developed Countries," in Alan Sorkin et al., eds. Research in Human Capital and Development. Connecticut: Jai Press Inc., 1982.

Analysis of determinants of life expectancy in developing countries. Found a shift from the importance of economic indicators (i.e., GNP, income distribution) to the greater impact of social indicators (i.e., literacy, communication) in determining life expectancy. In period 1960-1965, 70\% of the variation in levels of life expectancy was associated with per capita income and literacy rates in a ratio of 3 to 2 in favor of economic variables. In period 1970-1975 the ratio was 6 to 1 in favor of literacy. In a multivariate model, looking at absolute change in life expectancy, found sanitation and heaith personnel (population per midwife) were significantly correlated with the change in life expectancy.

Haines, Michael R. and Avery, Roger C., "Differential Infant and Child Mortality in Costa Rica: 1968-1973," Cornell University, Department of Economics, November 1978.

Multivariate analysis applied to ecological and individual data from Costa Rica in an attempt to assess the separate effects of education, income, sanitation, housing, medical facilities and ambient mortality risks; found increased education of women appears to be significantly and negatively correlated with child mortality in a bivariate relationship; the relationship is not as strong in the ecological analysis, possibly because education operates through the utilization and demand for medical care services; the relationship also weakens somewhat in the micro-analysis when other variables are considered. 
Meegama, S.A., "Socioeconomic Determinants of Infant and Child Mortality in Sri Lanka: An Analysis of Post-War Experience," Scientific Reports, vol. 8, April 1980.

Study of differences in mortality in Sri Lanka by various socioeconomic variables based on data of 1975 World Fertility Survey. Age of mother and birth order both have a strong influence on neonatal mortality; but mother's level of education or literacy when controlled for other variables seems to have very little influence on neonatal mortality; postneonatal mortality seemed to be influenced mainly by environmental indicators. When child mortality was considered, the economic level of the household, environmental conditions and mother's literacy all seem to have an independent impact.

Panikar, P.G.K., "Resources Not the Constraint on Health Improvement," Economic and Political Weekly, November 3, 1979.

Exploration of why Kerala has a low infant mortality and high life expectancy even with low GNP and lack of resources. Litcracy level in Kerala is $60 \%$ as compared to a rate of $29 \%$ for all of India. Education in Kerala seems to result in higher utilization of services. Conclusion: preventive services (sanitation, etc.) and education of women are key to Kerala's improved health status.

Preston, Samuel H., "Mortality, Morbidity and Development," Population Division, mimeographed paper, September 20,1978.

Study to identify the factors responsible for mortality improvements in LDCs. Multiple regression based on a cross-sectional study of 120 countries around 1970 . Found rise of $10 \%$ in proportion of literates is associated with an increase of two years in the expectation of life at birth.

Puffer, Ruth Rice and Serrano, Carlos V., Patterns of Mortality in Childhood, PAHO, Scientific Publications, 1973.

Examination of problems underlying childhood mortality in Latin American projects. Among children of mothers with secondary or university education, high proportions of the deaths which occurred in the neonatal period were mostly due to certain perinatal causes. On the other hand, among mothers with no education, the proportion of deaths was high after the neonatal period. A high proportion of these deaths was due to infectious diseases and to a large extent related to nutritional deficiency. In this study, the education factor did include all other socioeconomic variables associated with mortality (i.e., income, housing, fertility, etc.).

Sloan, Frank, "Survival of Progeny in Developing Countries: An Analysis of Evidence from Costa Rica, Mexico, East Pakistan, and Puerto Rico," report prepared for AID (CA: Rand Corporation, July 1971).

An analysis of determinants of mortality in the under-fives in Costa Rica, Mexico, East Pakistan, and Puerto Rico. In general, found female literacy and nutrition were significant factors affecting infant and pre-school child mortality. The role of female labor force activity and medical care is less clear. Sanitation and housing variables provided no explanation of the variation in mortality. Study suggests four possible mechanisms through which education affects mortality: 1) increased awareness of personal hygiene, 2) the propensity of the literate to seek medical care from scientific rather than from folk sources, 3) cognitive development enabling the consequences of particular acts to be anticipated, particularly those associated with child care, and 4) greater efficiency in the consumption of goods and services.

\section{Studies Focusing on Education's Effect on Malnutrition and Morbidity in Children}

Bairagi, R., "Is Income the Only Constraint on Child Nutrition in Bangladesh?" Bulletin of the World Health Organization, vol. 58, no. 5, 1980, pp. 767-772.

Data came from 517 children under study in the Companigonj Health Project, Noakhali. A co- 
variance analysis revealed that income and mother's education were both significantly related to the nutritional status of the children. This study found that the improvement in nutritional status of the children of illiterate mothers with increasing income is slight whereas with literate mothers, there is a significant improvement of nutritional status with increasing income; suggests that a nutrition education programme would improve the nutritional status of the children at least among the upper income groups.

Gans, Bruno. "Some Socioeconomic and Cultural Factors in West African Paediatrics," Archives of Diseases in Childhood, vol. 38, 1963, pp. 1-12.

Elementary analysis of basic socioeconomic and cultural data to evaluate day to day paediatrics in large tropical town in West Africa (Lagos, Nigeria); surveyed 984 children and their mothers and fathers coming to OPD clinic. Found no significant difference between weight of children whose mothers were part of polygamous households; children of mothers belonging to higher socioeconomic groups weighed more than those of mothers of the lowest groups; father's socioeconomic group did not appear to affect their children's weight. Protein malnutrition, under-nutrition and birth injury were more common in children whose mothers belonged to the lower socioeconomic groups, were illiterate or belonged to polygamous households.

Knowles, James C., "Interactions Between Malnutrition and Disease: A Simultaneous Equations Model Applied to Data From a Low Income Area of Karachi." Pakistan, University of Karachi, September 1979.

Because of the difficulty in determining causality with typical regression models, a three-equation simultaneous equations model was employed in this study of a low income area of Karachi, Pakistan. Results of the study were that neither education variable (father's or mother's education) is statistically significant as a determinant of any of the endogenous variables (number of spells of diarrhea, number of spells of respiratory illness or nutrition measures). Study concludes that education of neither parent is a significant determinant of the child's nutrition status or the incidence of disease.

Leslie, J. and Cochrane, S., "Parental Education and Child Health: Malnutrition and Morbidity," draft for the World Bank, November 1972.

Examination of differentials in child malnutrition and morbidity by parental education in LDC's. Differences in child morbidity by education level of the mother are not as uniform as differences in malnutrition and mortality. Income has a clearer inverse relationship with morbidity than does maternal education and severity of illiness and/or early recognition and/or the response of the mother to the child's illness.

\section{Studies in the U.S. Which Support the Relationship Between Education and Health Status}

Comstock, George W. and Tonascia, James A., "Education and Mortality in Washington County Maryland," Journal of Health and Social Behavior, vol. 18, March 1977, pp. 54-61.

Study takes place in Washington County, Maryland. Findings: general trends of decreasing mortality with improved socioeconomic status; education is at least an indirect determinant of longevity. In U.S. education has increased significantly to $85 \%$ completion of high school in 1972 , but agestandardized death rate has declined only slightly after 1953 - why? 1) observed inverse association of mortality with education might be purely coincidental and not causal; or 2) there are unrecognized factors tending to cause an increase in death rates that counteract the beneficial effects of education.

Grossman, Michael, "Determinants of Children's Health," National Bureau of Economic Research, February 1980.

A study of determinants of child health based on the Health Examination Survey. Among the 
significant findings are that the home environment in general and mother's schooling in particular play an extremely important role in the determination of children's health. With birth weight, mother's age at birth, congenital abnormalities, other proxies for genetic endowment and family income held constant, parents' schooling has a positive and statistically significant effect on many measures of health in childhood and adolescence; children and teenagers of more educated mothers have better oral health, are less likely to be obese and less likely to have anemia than children of less educated mothers. Father's schooling plays a much less important role. Concludes that the effect of mother's schooling is behavioral as opposed to genetic.

Kitagawa, Evelyn M. and Hauser, Philip M., Differential Mortality in the United States. Massachusetts: Harvard University Press, 1973.

Study of the differential effects of education, income, occupation and geographic location on mortality in the U.S. Found that education is probably the single most important indicator of socioeconomic status for mortality analysis. Included among the findings was that infant mortality rates in the United States 1964-66 were inversely related to family income and to level of educational achievement of both parents. Infant mortality was $77 \%$ higher for mothers who had only an elementary school education than for mothers who had graduated from college. The differentials in infant mortality were very similar by level of education of father and only slightly less matched by family income.

Lefcowitz, Myron J., "Poverty and Health: A Re-Examination," Inquiry, vol. 10, no. 1, March 1973, pp. 3-13.

Utilized data from U.S. Center for Health Statistics. Findings: 1) education of the family head is an important factor in medical care utilization for the young; 2) persons in families where the head had less than nine years of schooling are less likely to have used service. The relationship between health and poverty as indicated by morbidity is not proven. When mortality rates are used as an indicator, education again is the socioeconomic variable most closely related. Hypothesis: health related and health oriented behaviors are primarily a function of valued lifestyles and education is primary agent in the development of such tastes. Education helps a family order its priorities for acquiring goods and services. Alternative hypothesis: education is a proxy for permanent income; author supports first hypothesis; suggests increasing the preference for health care among the lower educated through outreach workers, medical translators, and reinforcement of preferred behaviors which are causally linked to health.

Wolfe, Barbara L., "Children's Utilization of Medical Care," Medical Care, vol. 18, no. 12, pp. 1196 1207.

Analysis of access to medical care in Rochester, New York (a city with a major pediatric project and in a state with the most generous Medicaid benefits in the nation). Study found that children in families who live in areas with higher incomes are more likely to receive care; children in larger families are less likely to get medical care; women who work full time seem to take their children to providers less frequently; income, race, marital status, family size, type of insurance coverage and community characteristics are all associated with type of provider used; children with more resources (in terms of income, parent's time, community income and insurance) appear more likely than other children to use higher quality care. Concludes these differences in utilization may respond to education (e.g., providing information to young, pregnant women, unmarried women and women with many children on the services they can and should obtain).

\section{Studies Which Focus on the Mechanisms of Interaction Between Education and Health Status}

Levine, Robert A., "Women's Education and Maternal Behavior in the Third World," a report to the Ford Foundation, August 1978.

Focus of the paper is maternal behavior as it affects child's cognitive development. Concludes there 
is no firm basis for believing that maternal education exerts an effect independent of wealth and other factors on the nutrition, physical growth and health of the child. Offers several alternative hypotheses: more educated women have parents who are more educated who give them certain advantages, or more educated women marry men of greater education. Establishes guidelines for research: 1) data should be collected on maternal attitudes, maternal behavior, behavior of infants; 2) socioeconomic and educational background on women's parents, women's husbands, other caretakers of child; 3) multivariate and causal inference techniques of maternal education and outcomes.

O'Hara, Donald J., "Toward a Model of the Effects of Education on Health," draft, January 1980.

Cautionary note on speaking of education as a determinant of health. Education and health are merely joint outcomes of individual and household decisions. Agrees that parental education does have an influence on child's health: 1) effects of education on health in general, market and non-market influences of education, education's affect on tastes of consumer; 2) whose education and whose health is important? Question of simultaneous determination of health and education is raised.

Rosenzweig, Mark R. and Schultz, T.P., "Birthweight, The Production of Child Health and the Input Demand," mimeographed paper, June 1980.

Economic model of the household for determining the activities affecting the size of children at birth and gestation and determining the biological, technical relationships between parental behavior and birth outcomes in the presence of population heterogeneity. Section on education, information and the production of child health. Education may affect parental perceptions of the relation of inputs and outputs of household production; therefore, in order to use a model to predict health outcomes, need to relate the perceptions to observable characteristics or distributional characteristics of perceptions or "perception errors."

\section{Bibliography}

Ademuqagun, S.A., Solu Oduntan and Familusi, J.B., "Mother and Child Health in Africa: The Role of Health Education," Israel Journal of Medical Science, vol. 13, no. 5, May 1977, pp. 508-513.

Ali-Isi, I., Kanawati, A. and McLaren, D.S., "Formal Education of Mothers and Their Nutritional Behavior," Journal of Nutrition Education, vol. 7, 1975, pp. 22-24.

Anderson, C Arnold and Bowman, Mary Jean, eds., Education and Economic Development. Chicago: Adine Publishing Co., 1965.

Arriaga, Eduardo E. and Davis, Kingsley, "The Pattern of Mortality Change in Latin America," Demography, vol. 6, no. 3, August 1969, pp. 223-242.

Bairagi, R., "Is Income the Only Constraint on Child Nutrition in Bangladesh?" Bulletin of the World Health Organization, vol. 58 , no. 5,1980 , pp. 767-772.

Behm, Hugo, "Socioeconomic Determinants of Mortality in Latin America," paper presented at WHO Meetings on Socioeconomic Determinants and Consequences of Mortality, June 1979.

Blaug, Mark, Economics of Education. Maryland: Penguin Books, Inc., 1968.

Caldwell, John C., "Education as a Factor in Mortality Decline - An Examination of Nigerian Data," Population Studies, vol. 33, no. 3, November 1979, pp. 395-413.

Castule, W.M., "Occupation, Education and Income as Socioeconomic Indicators in Relation to Cardiovascular Risk Factors in the Urban African," Bulletin of the World Health Organization, vol. 56 , no. 3,1978 , pp. $457-459$.

Cipolla, Carlo M. Literacy Development in the West. Maryland: Penguin Books, 1969.

Clark, Noreen M. Education for Development and the Rural Woman. N.Y.: World Education, 1979.

Cochrane, Susan H., "Educational Differentials in the Mortality of Children," mimeographed paper, April 1980.

Cochrane, Susan H. Fertility and Education: What Do We Really Know? Maryland: Johns Hopkins Press, 1979. 
Cochrane, Susan H., "The Socioeconomic Determinants of Mortality: The Cross-National Evidence," discussion draft for WDR, January 2, 1980.

Comstock, George W. and Tonascia, James A., "Education and Mortality in Washington County Maryland," Journal of Health and Social Behavior, vol. 18, March 1977, pp. 54-61.

Elliot, Jean Leonard, "Cultural Barriers to the Utilization of Health Services," Inquiry, vol. 9, December 1972, pp. 28-35.

Fauquee, Rashid, "Sources of Fertility Decline: Factor Analysis of Inter-country Data," World Bank Staff Working Paper No. 318, February 1979.

Fernando, Dallas F.S., "Nuptiality, Education, Infant Mortality and Fertility in Sri Lanka," Journal of Biosocial Science, vol. 11, 1979, pp. 133-140.

Fredericksen, Harald, "Determinants and Consequences of Mortality and Fertility Trends," Public Health Reports, vol. 81, no. 8, August 1966, pp. 715-727.

Gaise, S.K., "Some Aspects of Socioeconomic Determinants of Mortality in Tropical Africa," paper presented at WHO Meeting on Socioeconomic Determinants and Consequences of Mortality, June 1979.

Gans, Bruno, "Some Socioeconomic and Cultural Factors in West African Paediatrics," Archives of Diseases in Childhood, vol. 38, 1963, pp. 1-12.

Grosse, Robert N., "Interrelation Between Health and Population: Observations Derived from Field Experiences," Bellagio Conference on Health and Population in Developing Countries, April 1979.

Grosse, Robert N. and Perry, Barbara H., "Correlates of Life Expectancy in Less Developed Countries," in Alan Sorkin et al., eds., Research in Human Capital and Development. Connecticut: Jai Press Inc., 1982.

Grossman, Michael, "Determinants of Children's Ilealth," National Bureau of Economic Research, February 1980.

Gwatkin, Davidson, "The End of an Era," Overseas Development Council, May 1980.

Haines, Michael R. and Avery, Roger C., "Differential Infant and Child Mortality in Costa Rica: 1968-1973," Cornell University, Department of Economics, November 1978.

Harrington, Judith A., "Economic Development and Mortality in Infancy and Childhood: Comments from the West African Case," Population Planning Working Paper No. 10, The University of Michigan. Undated.

Hull, Terence H, and Hull, Valerie J., "The Relation of Economic Class and Fertility: An Analysis of Some Indonesian Data," Population Studies, vol. 31, No. 1, March 1977, pp. 73-87.

Jones, Gavin, Population Growth and Educational Planning in Developing Countries. New York: Irvington Publishers, Inc., 1975.

Khalifa, Atef, "The Influence of Wife's Education on Fertility in Rural Egypt," Journal of Biosocial Sciences, vol. 8, 1976, pp. 53-60.

Kirk, Dudley, "A New Demographic Transition?" in Rapid Population Growth. Maryland: Johns Hopkins Press, 1971.

Kitagawa, Evelyn M. and Hauser, Philip M., Differential Mortality in the United States. Massachusetts: Harvard University Press, 1973.

Knowles, James C. "Interactions Between Malnutrition and Disease: A Simultaneous Equations Model Applied to Data from a Low-Income Area of Karachi" (Pakistan: University of Karachi, September 1979).

Lefcowitz, Myron J., "Poverty and Health: A Re-Examination," Inquiry, vol. 10, no. 1, March 1973. pp. 3-13.

Leslie, J. and Cochrane, S., "Parental Education and Child Health: Malnutrition and Morbidity," draft for the World Bank, November 1979.

Levine, Robert A., "Women's Education and Maternal Behavior in the Third World," a report to the Ford Foundation, August 1978.

Mauldin, W. Parker and Berelson, Bernard, "Conditions of Fertility Decline in Developing Countries, 1965-1975," Studies in Family Planning, vol. 9, no. 5, May 1978.

McNamara, Robert S. "Possible Interventions to Reduce Fertility," Population and Development Review, vol. 3, 1977, p. 165.

Meegama, S.A., "Some Socioeconomic Determinants of Infant and Child Mortality in Sri Lanka: An Analysis of Post-War Experience," Scientific Reports, no. 8, April 1980. 
Meyer, John W. and Hannan, Michael T., National Development and the World System. Chicago: The University of Chicago Press, 1979.

Nagi, Mostafa H. and Stockwell, Edward G., "Socioeconomic Differentials in Mortality by Cause of Death," Health Service Reports, vol. 88, no. 5, May 1973, pp. 449-456.

Nair, P.R. Gopinathan, "Decline in Birth Rate in Kerala," Economic and Political Weekly, February 1974.

O'Hara, Donald J., "Toward a Model of the Effects of Education on Health," draft, January 1980.

Panikar, P.G.K., "Resources Not the Constraint on Health Improvement," Economic and Political Weekly, November 1979.

Plank, S.J. and Milanesi, M.L., "Infant Feeding and Infant Mortality in Rural Chile," Bulletin of the World Health Organization, vol. 48, 1973, pp. 203-210.

Popenoe, Oliver, "The Importance of Education in National Development," in Morgan and Betz, eds., Economic Development, Readings in Theory and Practice. California: Wadsworth Publishing Company, Inc., 1970.

Preston, Samuel H., "Causes and Consequences of Mortality Decline in Less Developed Countries During the Twentieth Century," paper presented at 1976 Conference on Population and Economic Change in Less Developed Countries.

Preston, Samuel H. and Nelson, Verne E., "Structure and Change in Causes of Death: An International Summary," Population Studies, vol. 28, no. 1, pp. 19-51.

Puffer, Ruth Rice and Scrrano, Carlos V., Patterns of Mortality in Childhood. Pan American Health Organization, Scientific Publication, 1973.

Rodgers, G.B., "Income and Inequality as Determinants of Mortality: An International Cross Section Analysis," Population Studies, vol. 33, no. 2, July 1979.

Rosenzweig, Mark R. and Schultz, T.P., "Birthweight, the Production of Child Health and the Input Demand," mimeographed paper, June 1980.

Rossi, Alice S., "Family Development in a Changing World," American Journal of Psychiatry, vol. 128, no. 9, March 1972, pp. 1057-1066.

Simmons, George B., "The Policy Implications of the Relationship Between Fertility and Socioeconomic Status," Population Planning Working Paper No. 24, University of Michigan, June 1977.

Sloan, Frank, "Survival of Progeny in Developing Countries: An Analysis of Evidence from Costa Rica, Mexico, East Pakistan, and Puerto Rico," report prepared for AID. California: Rand Corporation, July 1971.

Stockwell, Edward G. and Hutchinson, Bruce W., "A Note on Mortality Correlates of Economic Development," Population Review, vol. 19, January-December 1975, pp. 46-50.

Wolfe, Barbara L. , "Children's Utilization of Medical Care," Medical Care, Vol. 18, No. 12, pp. 11961207.

World Bank, Education Sector Working Paper, 1980.

World Health Organization, Reports on Social and Biological Effects on Perinatal Mortality, vol. 1, no. 2, 1978.

Yankauer, Alfred, "An Approach to the Cultural Base of Infant Mortality in India," Population Review, vol. 3, no. 2, July 1959, pp. 39-51. 